\title{
Tolerogenic Mechanisms in Liver Transplantation
}

\author{
Elaine Y. Cheng ${ }^{1,2 *}$, Paul I. Terasaki ${ }^{1}$ \\ ${ }^{1}$ Terasaki Foundation Laboratory, Los Angeles, California, USA \\ ${ }^{2}$ Department of Surgery, David Geffen School of Medicine at University of California, Los Angeles
}

Received: August 17, 2015; Accepted: September 22, 2015; Published: October 31, 2015

*Corresponding author: Elaine Y. Cheng, Terasaki Foundation Laboratory, 11570 W Olympic Blvd, Los Angeles, CA 90064, USA, Tel: +310-479-

6101; Fax: +310-445-3381; E-Mail: echeng@terasakilab.org

\begin{abstract}
Absract
The liver has unique tolerogenic properties which have been recognized since the beginning of liver transplantation. The liver allograft not only demonstrates a lower incidence of rejection compared with other solid organs, but it also has the ability to protect other organs from the same donor against rejection and graft loss. Up to $20 \%$ of liver transplant recipients have been successfully weaned from immunosuppressive therapy while maintaining stable allograft function. Furthermore, the liver has the ability to reverse ongoing rejection of other transplanted organs and counters the deleterious effects of preformed lymphocytotoxic antibodies. Various mechanisms have been proposed to explain the immunomodulatory properties of the liver. These include: (1) the transfer of donorderived hematopoietic cells, called passenger leukocytes, with the liver graft and the creation of donor microchimerism; (2) the role of hepatocytes and non-parenchymal liver cells as tolerogenic antigen presenting cells; (3) the high-dose antigen effect leading to dilution of cytokines and clones of alloreactive T cells; and (4) the introduction of soluble and cell-bound major histocompatibility complex class I molecules by the liver graft. This article will examine the evidence underlying each of these hypotheses and assess their relative significance in the induction and maintenance of donor-specific hyporesponsiveness. An enhanced understanding of the immune processes responsible for transplantation tolerance may lead to the identification of biomarkers for the prediction of graft outcomes. More importantly, this knowledge may facilitate the development of therapeutic strategies to promote indefinite allograft acceptance, while eliminating or minimizing the need for immunosuppressive drugs.
\end{abstract}

Keywords: Transplantation tolerance; Liver transplantation; Chimerism; Antigen presentation; Soluble MHC molecules

\section{Introduction}

The tolerogenic capacity of the liver has been described since the earliest days of experimental Liver Transplantation (LT). In 1967, Roy Calne reported the prolonged survival of transplanted liver grafts between genetically disparate pigs [1]. Despite the absence of immunosuppression, the recipients remained immunologically unresponsive to the liver graft and other tissues from the same donor $[2,3]$. These findings were later confirmed in mice [4] and between certain strains of rats [5,6]. Furthermore, the liver graft can act as an immunosuppressive agent and reverse ongoing rejection of other transplanted organs [7-9].

In clinical transplantation, the liver experiences a lower incidence of rejection compared with other solid organs, and spontaneous acceptance of the liver graft with successful discontinuation of immunosuppression has been reported in nearly $20 \%$ of LT recipients [10,11]. Multiple studies have suggested the protective effect of the liver allograft in Simultaneous Liver-Kidney Transplantation (SLKT) compared with recipients of isolated renal transplants; SLKT recipients demonstrate a lower frequency of kidney rejection as well as improved long-term survival [12-14]. Among sensitized kidney transplant recipients with positive lymphocytotoxic crossmatches, inclusion of the liver graft reverted the crossmatch to negative within 1 hour of reperfusion, and prevented the occurrence of hyperacute rejection $[15,16]$. The protective effect of simultaneous LT extends to other solid organ grafts, as the observed incidence of intestinal allograft rejection is reduced in combined liver-intestine transplant recipients [17].

Various mechanisms have been proposed for the immunomodulatory properties of the transplanted liver (Figure 1). It has been shown that the liver harbors donor-derived hematopoietic cells, called passenger leukocytes, which are transferred to the recipient at the time of transplantation. Donor microchimerism, or the persistence of donor cells and nucleic acid in the blood and tissues of the recipient, has been postulated to promote long-term graft survival. Hepatocytes and nonparenchymal cells within the liver are thought to play an important role in the modulation of the $\mathrm{T}$ cell response which contributes to tolerance. An alternative hypothesis suggests that the large size of the liver graft creates a high antigen dose which overwhelms the recipient alloimmune response. Another attractive theory involves the absorption and/or neutralization of alloreactive antibodies by the membrane-bound and soluble forms of Major Histocompatibility Complex (MHC) class I molecules introduced by the liver allograft. In this review, we will examine the experimental and clinical evidence underlying each hypothesis, and integrate these concepts for an enhanced understanding of transplantation tolerance.

\section{Passenger Leukocytes and Donor Microchimerism}

The liver contains large numbers of donor-derived passenger leukocytes which migrate out of the graft immediately after transplantation and can persist in the recipient for some time 


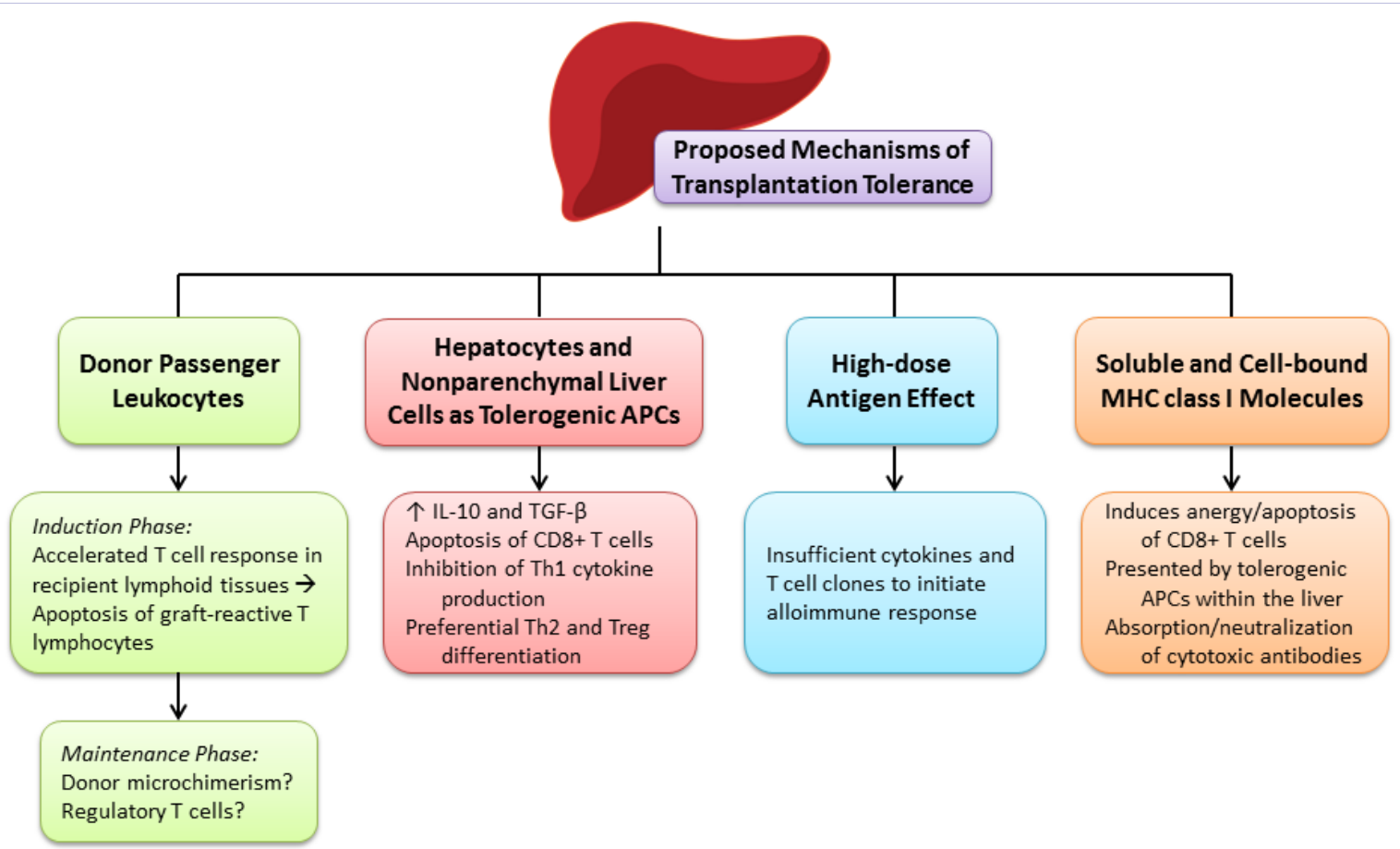

Figure 1: Schematic illustrating the proposed tolerogenic mechanisms in liver transplantation. The putative contributions of donor passenger leukocytes, hepatocytes and non-parenchymal liver cells as tolerogenic Antigen-Presenting Cells (APCs), the high-dose antigen effect, as well as soluble and cell-bound Major Histocompatibility (MHC) class I molecules are presented.

[18], creating a state of peripheral microchimerism. Donor microchimerism is frequently seen among LT recipients [19], leading to the hypothesis that chimerism plays an important role in tolerance induction. In the early 1990s, Starzl, et al. [20,21] demonstrated that microchimerism can persist in liver recipients greater than 10 years post-transplant, all of which maintained good graft function while some were able to discontinue immunosuppressive therapy.

Early evidence for the role of chimerism in allograft acceptance comes from experimental and clinical observations with donor-specific blood transfusions. Administration of donor whole blood into rat cardiac transplant recipients generated chimerism [22], and resulted in the complete suppression of rejection and induction of graft tolerance $[23,24]$. Similar results were obtained with a single injection of donor splenocytes at the time of transplantation, which causes downregulation of T-cell mediated alloreactivity within the allograft $[25,26]$. On the other hand, depletion of passenger leukocytes by donor irradiation abolishes tolerance and increases the risk of allograft rejection $[27,28]$. The use of chimeric rat liver grafts confirmed that, the presence of donor-derived passenger leukocytes is necessary for tolerance induction $[29,30]$. Attempts to promote chimerism in humans have been made using donor-derived bone marrow cell infusions. This strategy has reduced the incidence of acute and chronic rejection among solid organ transplant recipients [31], and afforded a modest improvement in the long-term survival of kidney allograft [32,33]. Clinical trials are now underway to further elucidate the effects of donor bone marrow infusion in association with non-ablative conditioning in solid organ transplantation [34].

\section{Passenger leukocytes in the induction of tolerance}

Upon reperfusion of the liver allograft, passenger leukocytes migrate to recipient lymphoid tissues [35], where they trigger a rapid and vigorous alloimmune response. Host $\mathrm{T}$ cells are activated by means of direct antigen presentation pathway and proliferate in the draining lymph tissues [36,37], leading to marked increases in Interleukin-2 (IL-2) and Interferon- $\gamma$ (IFN- $\gamma$ ) expression within the first day after transplantation $[35,38]$. This paradoxical early immune activation is more vigorous and greater in magnitude than the immune responses observed during rejection.

Host $\mathrm{T}$ cells activated in this manner are unable to initiate rejection and instead undergo apoptosis within the recipient lymphoid tissues. The remaining activated $\mathrm{T}$ lymphocytes travel back to the liver allograft, where they also undergo programmed cell death [37]. Evidence in support of this theory stems from the observation that large numbers of apoptotic leukocytes accumulate within the spleen and liver graft by day 2 posttransplant [39]. The end result of this process is the clonal deletion of donor-reactive $\mathrm{T}$ lymphocytes, and the induction of hyporesponsiveness towards donor-specific antigens [40].

The precise mechanisms leading to apoptosis of activated donor-reactive $\mathrm{T}$ cells remain elusive. Despite dramatic increases in the production of IL-2 and IFN- $\gamma$ shortly after liver transplantation, some studies have suggested that the 
concentrations of these cytokines are insufficient to support the vigorous host $\mathrm{T}$ cell response described above, leading to death by neglect of alloreactive $\mathrm{T}$ cells [40]. Other studies, however, indicate that the role of IL- 2 in tolerance may be more complicated. For instance, there is evidence showing that IL-2 can sensitize $\mathrm{T}$ cells to Fas-mediated cell death $[41,42]$. While exogenous IL-2 has been shown to decrease T cell apoptosis and induce rejection in spontaneously accepted rodent liver allografts $[43,44]$, the administration of an IL-2 receptor antagonist also prevented tolerance, possibly via the reduction of regulatory $\mathrm{T}$ (Treg) cells [45]. In clinical liver transplantation, multiple immunosuppressive agents are often given in combination during the immediate post-transplant period. Each of these agents can exert distinct effects on $\mathrm{T}$ cell activation and apoptosis. Cyclosporin and tacrolimus, commonly-used calcineurin inhibitors, reduce the transcription of IL-2 and related cytokines. On the other hand, the administration of corticosteroids during the induction phase decreases the production of IL- 2 and IFN- $\gamma$, abrogates $\mathrm{T}$ cell apoptosis and impairs the development of donorspecific tolerance [35].

Despite the multitude of studies supporting the role of passenger leukocytes in tolerance induction, the particular donor cell types involved have not been clearly defined. Characterization of donor lymphocytes transferred with the liver graft revealed a predominance of partially activated $\mathrm{T}$ and Natural Killer (NK) cells, while smaller numbers of resting $\mathrm{T}$ and $\mathrm{B}$ cells are transmitted by the lymph nodes associated with the graft [46]. Experimental studies in rodents suggested that donor-derived $\mathrm{T}$ cells are needed to regulate tolerance induction [28,47], while other reports have implicated the involvement of Dendritic Cells (DC) $[24,48]$. Recently, Moroso, et al. [49] observed that the liver harbors an abundance of NK cells, which contain perforin and granzymes and exhibit potent cytolytic activity, suggesting that NK cells may play a role in the regulation of alloimmune responses. Further experiments from the same laboratory, however, showed that the depletion of hepatic NK cells failed to abrogate liver allograft acceptance [50].

\section{Donor microchimerism and the maintenance of tolerance}

Although Starzl, et al. [20] postulated that peripheral microchimerism is responsible for the long-term survival of liver allografts, the available literature does not show a clear association between chimerism and the recipient's immunological status [51]. For instance, a number of studies have reported the occurrence of rejection despite the presence of donor chimerism, and microchimerism does not necessarily correlate with longterm allograft survival [52-55]. Furthermore, while the depletion of donor passenger leukocytes on the day of transplantation (day 0 ) prevented tolerance induction, depletion on day 18 after transplant had no apparent effects on graft acceptance [56].

Some authors have proposed that the persistence of donor antigen, rather than microchimerism, is responsible for the maintenance of tolerance. The presence of donor antigen, not microchimerism, is a prerequisite for the induction of donor- specific hyporesponsiveness [57]. Evidence from murine models of transplantation indicates that the continuous supply of antigen, provided by the allograft itself, is also essential during the maintenance phase $[58,59]$. In particular, removal of the allograft from tolerized animals leads to the eventual loss of tolerance [60]. Since CD4+ Treg cells require the continuous presence of donor antigens to survive in tolerance models, it has been suggested that Tregs may play a critical role in maintaining tolerance. Alloreactive $\mathrm{T}$ cells are likely to be suppressed by Tregs in the presence of donor antigen, whereas removal of the allograft decreases the number or activity of Treg cells, in turn favoring the activation or expansion of alloreactive T cells [61].

Data from recent immunosuppressive drug weaning or withdrawal trials have provided additional insight into the important processes critical for the maintenance of tolerance. To aid in the selection of patients eligible for immunosuppression withdrawal, gene expression analyses and immunophenotyping studies have been carried out to identify biomarkers of graft acceptance. Microarray profiling of peripheral blood samples has revealed the preferential expression of NK cell transcripts in tolerant LT recipients [62-64]. Pathways involved in iron homeostasis havealso been implicated, as tolerant patients exhibit higher serum levels of hepcidin and ferritin, and demonstrate increased iron deposition within hepatocytes [65]. A selective expansion of $\gamma \delta \mathrm{T}$ cells, a subset of innate-type lymphocytes that can exhibit a regulatory phenotype, have been reported among tolerant recipients $[62,66,67]$. Furthermore, peripheral blood concentrations of CD4+CD25+ Treg cells and Foxp3 expression increased upon the withdrawal of immunosuppression in tolerant patients, a phenomenon not observed in patients who suffered rejection [68-70].

\section{Hepatocytes and Nonparenchymal Liver Cells}

Experimental evidence from rodent models of liver transplantation suggests that donor passenger leukocytes alone are not sufficient to prolong graft survival indefinitely, and that the liver parenchyma itself participates in the induction of antigen-specific tolerance [29,71]. In addition to hepatocytes, the liver graft contains nonparenchymal cells such as Kupffer Cells (KC), Liver Sinusoidal Endothelial Cells (LSEC), resident DCs, and stellate cells. These cellular compartments are organized into an unique structure within the sinusoids which enables direct interaction between the hepatic cells and circulating lymphocytes (Figure 2). The fenestrated endothelium of liver sinusoids, along with the low velocity of blood flow, allows for antigen presentation by hepatocytes and other nonparenchymal liver cells to T lymphocytes that pass through the liver [72,73].

\section{Hepatocytes}

Hepatocytes constitutively express MHC I molecules at high levels, while MHC II expression can be induced following inflammation. Hepatocytes have been shown to act as efficient Antigen-Presenting Cells (APC) for naïve CD4+ and CD8+ T lymphocytes, but such interactions appear to be tolerogenic as they result in the loss of cytolytic function and premature $\mathrm{T}$ cell death [74-76]. 


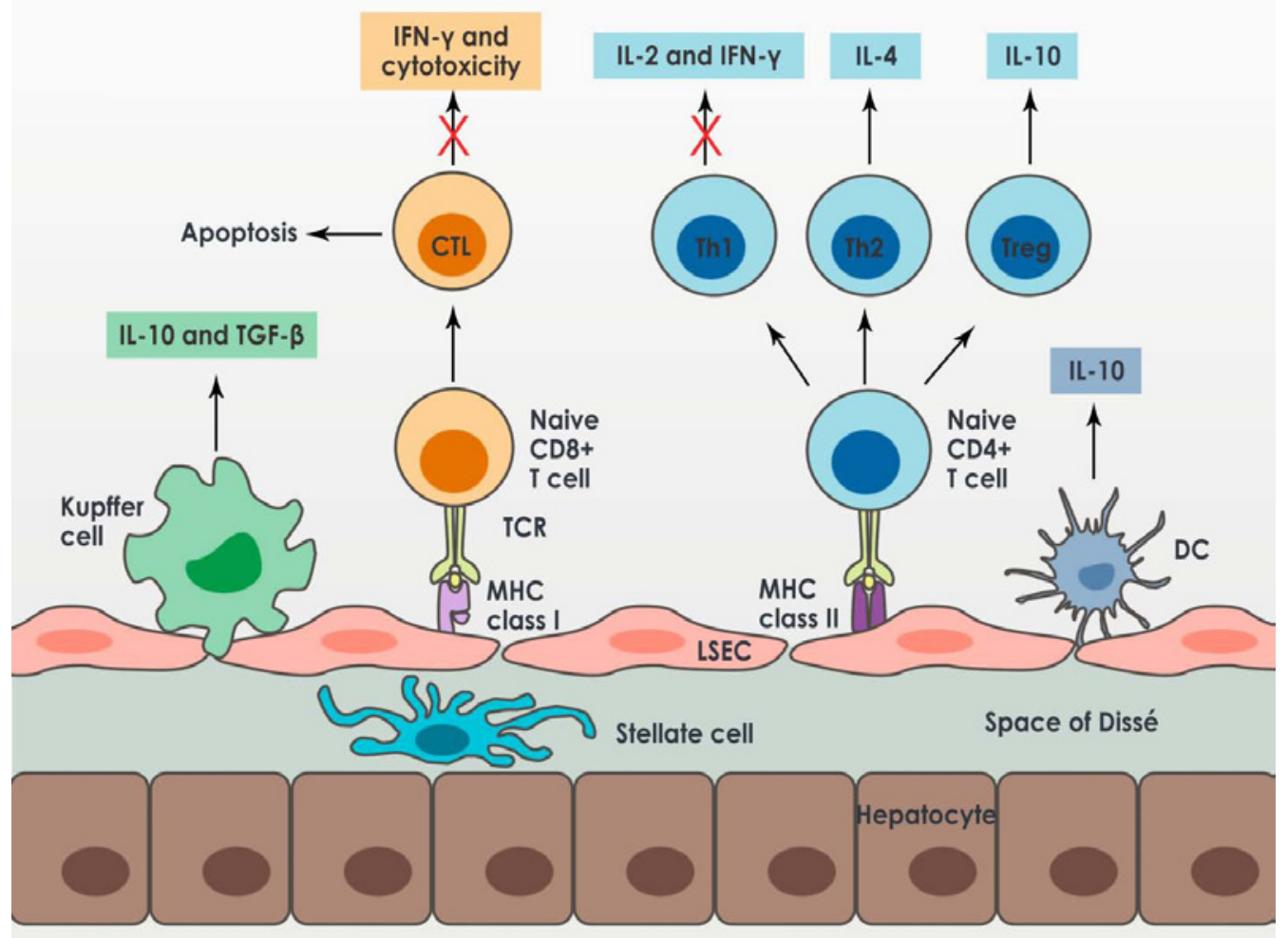

Figure 2: Cellular architecture and interactions within the liver. The fenestrated endothelium of the hepatic sinusoids allows the passage of large molecules into the subendothelial space of Dissé. Antigen presentation by Liver Sinusoidal Endothelial Cells (LSEC) to naïve CD8+ T cells leads to the development of Cytotoxic T Lymphocytes (CTL) deficient of cytotoxicity and a propensity for cell death by apoptosis. The interaction between LSEC and naïve CD4+ T cells favors differentiation towards Th2 and regulatory T (Treg) cell phenotypes, and suppresses cytokine production by Th1 cells. Kupffer cells, in conjuction with LSECs, produce IL-10 and TGF- $\beta$ which contribute to the tolerogenic environment within the liver. Hepatic Dendritic Cells (DC) also secrete the immunomodulatory cytokine IL-10 and play an important role in tolerance induction.

\section{Kupffer cells}

KCs are hepatic macrophages residing within the sinusoidal lumen. In vitro evidence suggests that KCs express MHC class II and co-stimulatory molecules, and can function as APCs for allospecific T cells [77]. Shortly after liver allograft reperfusion, KCs secrete massive amounts of IL-10 [78-80], a dominant cytokine within the liver which exerts multiple immunomodulatory effects $[81,82]$. KCs have also been shown to release nitric oxide and prostaglandins which may suppress $\mathrm{T}$ cell activation $[83,84]$. Perhaps more importantly, KCs can initiate apoptosis of alloreactive T effector cells via the Fas/ Fas ligand (FasL) pathway. These findings were confirmed by the addition of anti-FasL blocking antibody to in vitro co-culture assays, which effectively abrogated $\mathrm{T}$ cell apoptosis. In a rat LT model, pretreatment of the recipient with gadolinium trichloride, a KC inhibitor, prompted allograft rejection by means of FasL suppression [85].

\section{Liver sinusoidal endothelial cells}

LSECs play a critical role in hepatic immune surveillance by clearing antigens in the blood, often in the form of immune complexes [82]. LSECs express MHC class II molecules and possess the ability to present antigens to CD4+ and CD8+ T lymphocytes [86]. Naïve T cells activated by LSECs, however, do not differentiate into effector $\mathrm{T}$ cells and instead display a functional phenotype and cytokine profile compatible with tolerance. CD4+ T cell activation by LSEC does not lead to Th1 differentiation, but rather induces a regulatory phenotype characterized by IL-4 and IL-10 expression [87]. The adoptive transfer of transgenic CD4+ T cells into a murine model showed that LSECs selectively suppressed cytokine production by Th1 cells, while promoting the expansion of Th2 and regulatory $\mathrm{T}$ cells [88]. On the other hand, CD8+ T cells activated by LSECs show impaired proliferative ability, low expression of IL-2, and increased susceptibility to apoptosis $[89,90]$. More recent studies have revealed that the interaction of LSEC with naïve CD8+ T cells triggers LSEC maturation involving the expression of the negative co-stimulatory molecule programmed death-ligand 1 (PD-L1), which leads to the generation of tolerized CD8+ T cells devoid of cytotoxic activity [91].

\section{Dendritic cells}

DCs are professional APCs which have the capacity to effectively initiate immunity, but under certain conditions DCs can induce antigen-specific unresponsiveness [92]. KCs and LSECs within the liver constitutively secrete IL-10 and Transforming Growth Factor-B (TGF- $\beta$ ), creating a milieu which 
subverts DC maturation and function $[48,93,94]$. Accordingly, freshly isolated resident hepatic DCs are phenotypically and functionally immature, expressing low levels of surface MHC and co-stimulatory molecules $[95,96]$. Antigen presentation mediated by immature DCs (iDC) is unable to initiate effective proliferation of alloreactive $\mathrm{T}$ cells, and instead induces donorspecific hyporesponsiveness $[97,98]$. At least four distinct DC subsets have been identified within the mouse liver, and variations in subtype composition have been proposed to account for the tolerogenic properties of hepatic DCs [99]. Plasmacytoid DCs, which have the capacity to induce tolerance in the steady state, are found more commonly in the liver than in the spleen. The immunostimulatory myeloid and lymphoid DCs, on the other hand, only account for approximately $20 \%$ of the liver DC population, whereas they make up the vast majority of spleen DCs [96].

Resident DCs in the liver inhibit CD8+ T cell effector function and facilitate $\mathrm{Th} 1$ cell apoptosis while promoting Th2 generation and Treg development in an IL-10-dependent manner [100-102]. Human monocytes differentiated into DCs following co-culture with rat LSECs secrete IL-10, and preferentially direct Th2 over Th1 responses [103]. Furthermore, the relative abundance of plasmacytoid DCs in the liver may promote the induction and expansion of Foxp3+ Treg cells [104,105]. Under steady state conditions, DCs also have been shown to mediate CD8+ T cell tolerance via the co-inhibitory molecules Programmed Death-1 (PD-1) and cytotoxic T-lymphocyte-associated antigen 4 (CTLA4) [106].

The tolerizing effects of resident hepatic DCs have been demonstrated in vivo mostly in murine cardiac transplant models. iDCs administered to immunocompetent recipients 7 days prior to the transplantation were able to prolong cardiac allograft survival, which was accompanied by markedly blunted cytotoxic T lymphocyte reactivity. Expression of B7-1 and B7-2 molecules was up-regulated on donor-derived DCs within the recipient lymphoid tissues, implicating involvement of the CTLA4 pathway [107]. The survival of heart allografts was further extended with the co-administration of donor-derived iDCs with anti-CD40 ligand antibody, illustrating the importance of costimulatory signals in the functional interaction between DCs and T cells [108]. On the contrary, enhancing the function of DCs by donor pretreatment with a hematopoietic growth factor (Flt3ligand) elicited a potent allostimulatory response mediated by host T cells which led to allograft rejection [109].

\section{Hepatic Stellate Cells (HSC)}

HSCs constitute less than $8 \%$ of the total number of cells within the liver, but exhibit unique tolerogenic properties that deserve special mention. HSCs store fats and vitamin A, and have the ability to function as potent APCs for protein and lipid antigens [110]. In response to cellular stress, HSCs transform into myofibroblasts which are responsible for the development of liver fibrosis and cirrhosis [111]. Activated HSCs acquire immunoregulatory functions and promote $\mathrm{T}$ cell apoptosis via the PD-L1/PD-1 pathway [112]. Moreover, vitamin A (retinol) and its active metabolite retinoic acid can modulate the immune response in a pleiotropic manner [113]. Of particular relevance in transplantation tolerance may be the induction of CD4+Foxp3+ Treg cells by HSCs in the presence of retinoic acid and TGF- $\beta$. When co-transplanted with hepatocytes, activated HSCs provided beneficial immunomodulatory effects and promoted transplanted cell engraftment in the liver [114]. HSCs have also been shown to protect pancreatic islet allografts from rejection in a murine islet transplantation model [115].

Taken together, the microenvironment of the liver allograft is a tolerogenic milieu rich in IL-10 and TGF- $\beta$. Under such conditions, resident hepatic DCs maintain a functionally immature phenotype. Antigen presentation by iDCs and other cellular subsets within the liver may lead to tolerance by the differentiation of naïve $\mathrm{T}$ cells into regulatory phenotypes, and by the apoptosis of recently activated CD4+ and CD8+ effector T cells. The end result of these mechanisms is the clonal deletion of graft-reactive $\mathrm{T}$ lymphocytes, and the induction of donor-specific hyporesponsiveness.

\section{The High-Dose Antigen Effect}

The liver is approximately 10 times larger than the heart or the kidney, and its large tissue mass has been postulated to dilute cytokines [116] and alloreactive T lymphocytes [117] leading to exhaustion of the host immune response. This hypothesis is predicated upon the assumption that a "critical mass" of graftreactive $\mathrm{T}$ cells is needed to initiate immunity, and a high antigen dose dilutes the finite $\mathrm{T}$ cell clones such that the activation threshold is not reached [118].

The earliest evidence in support of this hypothesis stems from skin grafting experiments in animals. While larger skin grafts are more rapidly rejected compared with smaller grafts, drastically increasing the size of the skin graft has the paradoxical effects of reduced rejection rates and prolonged survival [119121]. Subsequent studies in rats showed that the simultaneous transplantation of multiple organs, which increases antigen load, improves graft survival rates [122]. These findings were later affirmed in cyclosporin-treated swines, in which combined transplantation of the heart and kidney from the same donor prevented rejection of the cardiac graft [123].

In clinical transplantation, the antigen dose effect has been cited as a plausible explanation for the beneficial effects of combined liver-kidney transplantation on allograft outcomes. SLKT recipients have been shown to experience lower incidences of renal allograft rejection and enhanced survival in single-center $[12,14]$ as well as larger registry studies $[13,124]$. The survival benefit associated with SLKT appears to be donor-specific, as kidney grafts from a third-party donor were not protected from rejection or rejection-related graft loss [125]. The antigen dose effect has also been demonstrated among pediatric renal transplant recipients, in whom the use of larger adult-sized kidneys conferred an immunologic advantage with prolongation of a rejection-free state and improved graft function [126]. Conversely, the use of reduced-size partial liver grafts in rats has been correlated with the occurrence of accelerated severe 
rejection [127-129]. In human living donor LT, a positive T-cell crossmatch was of particular clinical relevance in the setting of small-for-size liver allografts, and independently predicted early postoperative mortality attributable to acute rejection episodes [130].

Further evidence in support of the antigen dose hypothesis originates from reports that the immunoprotective properties of simultaneous transplantation are not limited to the liver, and can be extended to other solid organs. For instance, the long-term survival of kidney grafts was equally high between recipients of liver-kidney and those receiving heart-kidney transplants [13]. The positive effects of dual-organ transplantation expand to heart, lung, and kidney allografts, with each organ being able to protect itself and one another from rejection [131-133]. In composite tissue transplantation, the entirety of allograft (including skin, subcutaneous tissues, muscle, bone, and blood vessels) elicits a lesser immune response compared with each of its individual components, and displays a lower rejection rate when compared with skin transplantation alone [134].

The high-dose antigen effect in isolation is likely not sufficient for tolerance induction. Some investigators have proposed that the number of donor-derived passenger leukocytes transferred is proportional to the size of the transplanted organ, and accordingly the benefits associated with larger grafts may be explained by the high number of donor leukocytes available. As mentioned previously, liver allograft acceptance in rats is contingent upon the presence of passenger leukocytes. When tissue mass is increased via the simultaneous transplantation of two hearts or two kidneys, the additional infusion of donor leukocytes was still necessary for successful tolerance induction [47]. Meanwhile, sensitized recipients of reduced-size liver allografts showed an increased risk of antibody-mediated rejection compared with recipients of full-size grafts, illustrating that the size effect is at least partially attributable to the liver's ability to neutralize lymphocytotoxic antibodies [135]. Taken together, these findings suggest that, alternative processes likely act in concert with the antigen dose effect to induce tolerance.

\section{Soluble and Cell-Bound MHC Class I Molecules}

The liver allograft releases large quantities of soluble MHC class I molecules, which persist in the recipient circulation at high concentrations as long as the graft is functional [136]. There is compelling experimental and clinical evidence in support of the role of soluble MHC on tolerance induction. The introduction of MHC class I alloantigen by intravenous administration of donor serum, or by genetically modified hepatocytes expressing MHC class I molecules, prevented rejection and prolonged allograft survival in rat liver and cardiac transplantation models [137140]. Various paradigms have been proposed to explain the mechanisms underlying the immunoregulatory effects of MHC class I molecules. These include:

(1) Soluble MHC class I molecules can interact directly with the T-cell receptor on alloreactive CD8+ T lymphocytes. By selective stimulation of the T-cell receptor in the absence of a costimulatory signal, soluble MHC induces T cell apoptosis rather

\section{than activation [141].}

(2) Soluble MHC acts as a source for donor peptides which are processed by APCs and presented to allospecific T cells. As detailed above, many cellular subtypes within the liver graft can function as tolerogenic APCs, which alter the Th1/Th2 balance, shift $\mathrm{T}$ cell differentiation into regulatory phenotypes and facilitate the clonal deletion of graft-reactive T cells via apoptosis.

(3) Soluble MHC class I molecules may neutralize lymphocytotoxic alloantibodies by direct binding.

In the clinical arena, soluble MHC may account for the favorable outcomes following liver grafting in the presence of preformed alloantibodies. Among sensitized recipients undergoing SLKT, the liver allograft has been shown to reverse positive crossmatches and prevent the development of hyperacute rejection $[15,16]$. More recent studies reported that LT can be safely performed across preexisting antibodies directed against donor Human Leukocyte Antigens (HLA), and the spontaneous clearance of preformed antibodies is commonly observed after transplantation of the liver [142]. These observations lend support to the notion that the liver allograft mediates the absorption and/or neutralization of circulating antibodies. Dar, et al. [143] demonstrated that antibodies directed against donor MHC class I antigens are preferentially cleared compared with class II antigens among combined liver-kidney transplant recipients. These findings are in keeping with the release of soluble MHC class I, but not MHC class II, molecules by the liver graft. On the other hand, alloantibodies directed against class II HLA antigens are likely to persist after transplantation, and are associated with inferior patient and graft outcomes following SLKT [144].

Using an extracorporeal liver hemoperfusion system, Guggenheim, et al. $[145,146]$ found that cell-bound MHC class I molecules may contribute to the neutralization of lymphocytotoxic antibodies. In sensitized rat cardiac allograft recipients, the application of liver hemoperfusion delayed hyperacute rejection and reduced the level of circulating antibodies. Histological examination of the liver revealed evidence of antibody deposition on KCs and LSECs, which express high levels of MHC antigens on their cell surfaces. Further experimentation showed that this process is donor-specific, as hemoperfusion with a third party liver failed to decrease the levels of circulating antibodies, and was associated with a markedly diminished prolongation of cardiac graft survival.

\section{Human leukocyte antigen $G$}

HLA-G is a non-classical MHC class I molecule with a multitude of immunomodulatory properties. Under physiologic conditions, HLA-G is expressed as a membrane-bound molecule on cell surfaces, and as a soluble form in bodily fluids. Several mechanisms have been proposed to explain the tolerogenic properties of HLA-G: inhibition of CD8+ T and NK cell cytotoxicity $[147,148]$; suppression of CD4+ T cell proliferation $[149,150]$; promotion of Th2 polarization [151]; inhibition of cell cycle progression in alloreactive $\mathrm{T}$ cells [152]; conversion of effector $\mathrm{T}$ 
cells to a regulatory phenotype via cell-to-cell transfer of HLA-G [153]; and induction of tolerogenic DCs [154]. In autoimmune disorders such as multiple sclerosis [155] and rheumatoid arthritis [156], elevated levels of soluble HLA-G have been linked with disease remission. In contrast, the increased expression of HLA-G in malignancies may have deleterious consequences, as HLA-G may represent an escape mechanism by which tumor cells evade the host immune response. Markedly increased levels of soluble HLA-G have been detected in the serum of patients with various types of malignancies including breast and ovarian cancer, acute leukemia, malignant melanoma, and multiple myeloma [157].

In transplantation, HLA-G expression has been linked with the maintenance of allograft function and freedom from rejection. Renal transplant recipients with soluble HLA-G detected in the serum experienced lower incidences of acute rejection, chronic allograft nephropathy and subsequent graft failure [158,159]. Higher levels of HLA-G expression on peripheral blood CD4+ $\mathrm{T}$ lymphocytes were found among renal transplant recipients with stable function compared to recipients with rejection [160]. The detection of HLA-G in the serum and tissues of cardiac transplant recipients was also associated with a lower risk of acute and chronic rejection [161]. The administration of immunosuppressive drugs (including cyclosporin, tacrolimus, and corticosteroids) prompted a notable increase in soluble HLA-G levels which was associated with improved graft acceptance [162-164].

In liver transplantation, high levels of HLA-G expression in serum and tissue samples have been associated with reduced occurrences of acute rejection [165]. In a comparison of recipients with operational tolerance to those with stable liver function or acute rejection, tolerant patients were found to have significantly higher levels of serum HLA-G. The expression of HLA-G on circulating monocytoid DCs of tolerant recipients was associated with enhanced Foxp3 expression, implicating the involvement of Treg cells in the induction of tolerance by HLA-G [166]. Recipients of combined liver-kidney transplants, but not kidney alone transplants, demonstrated high concentrations of serum HLA-G, which was associated with lower frequencies of hepatic and renal allograft rejection $[167,168]$. On account of the strong correlation between HLA-G expression and favorable outcomes after LT, HLA-G has been purported as a prognostic biomarker, a tool for immunosuppression monitoring, and as a potential molecular target for future therapeutic interventions $[165,169]$.

\section{Conclusion}

In pursuit of transplantation tolerance, extensive efforts have been made to investigate the mechanisms responsible for the immunomodulatory properties of the liver graft. There is experimental and clinical evidence in support of each of the mechanisms described in this report, and it is likely that several of these processes act in concert to establish donor-specific tolerance. Common to these hypotheses is that the liver is a dynamic participant in the process of graft acceptance - whether it is the transfer of donor-derived passenger leukocytes into recipient lymphoid tissues, or antigen presentation by hepatocytes and non-parenchymal liver cells, or the release of soluble MHC class I molecules leading to the suppression of alloimmune response. The dominant mechanism in each recipient may vary depending upon the conditions such as genetic compatibility with the donor, the immunologic status of the recipient, the degree of inflammation triggered by the peritransplant events, and the immunosuppressive agents administered.

During the induction phase of tolerance, donor-derived passenger leukocytes appear to play an important role via the initiation of an accelerated $\mathrm{T}$ cell response within recipient lymphoid tissues. The activated $\mathrm{T}$ lymphocytes then undergo apoptotic cell death within these lymphoid tissues and in the liver allograft. With a predominance of the immunomodulatory cytokine IL-10, APCs within the liver assume tolerogenic properties, and their interactions with circulating $\mathrm{T}$ lymphocytes lead to the preferential differentiation of naïve $\mathrm{T}$ cells into regulatory phenotypes and the induction of apoptosis. On the other hand, humoral immunity may be inhibited by the release of soluble MHC class I molecules which neutralize lymphocytotoxic antibodies. Additionally, antibodies may be absorbed by cells within the liver which contain an abundance of membrane-bound MHC molecules. Consistent with this phenomenon is the recent observation that antibodies directed against class II antigens are more likely to persist after LT compared with class I antibodies. As a consequence, the liver does not confer complete protection from preformed antibodies, particularly when class II antibodies are present.

In contrast to the process of tolerance induction, the mechanisms responsible for the maintenance of tolerance are less well elucidated. Initially, the persistence of donor microchimerism was thought to be an indicator of indefinite graft acceptance, but subsequent reports have failed to show a clear connection between chimerism and long-term graft survival. Biomarkers of graft acceptance in immunosuppressive drug minimization studies have implicated the involvement of NK and $\gamma \delta \mathrm{T}$ cells. Tolerant transplant recipients also demonstrate a relative abundance of CD4+CD25+ Foxp3-expressing regulatory T cells. Further studies are needed to elucidate the contribution by each cellular compartment in maintaining tolerance.

Based on the role of donor-derived leukocytes in graft acceptance, clinical trials have been designed to study the effects of donor bone marrow infusions in solid organ transplantation. The available results have only demonstrated a modest benefit on long-term graft survival, indicating that alternative protocols are likely needed to achieve transplantation tolerance. A better understanding of the mechanisms leading to indefinite graft survival will facilitate the discovery of novel strategies for tolerance induction. In particular, HLA-G has been shown to possess multiple immunomodulatory properties and has been associated with favorable transplant outcomes. Although HLA-G has already been considered as a prognostic biomarker, its role in tolerance induction and potential as a therapeutic target warrants further investigation. 


\section{Acknowledgements}

The authors are grateful to Ms. Anh Nguyen for assistance in graphical illustration.

\section{References}

1. Calne RY, White HJ, Yoffa DE, Binns RM, Maginn RR, Herbertson RM, et al. Prolonged survival of liver transplants in the pig. Br Med J. 1967;4(5580):645-648.

2. Calne RY, Sells RA, Pena JR, Davis DR, Millard PR, Herbertson BM, et al. Induction of immunological tolerance by porcine liver allografts. Nature. 1969;223(5205):472-476.

3. Houssin D, Gigou M, Franco D, Bismuth H, Charpentier B, Lang P, et al. Specific transplantation tolerance induced by spontaneously tolerated liver allograft in inbred strains of rats. Transplantation. 1980;29(5):418-419

4. Qian S, Demetris AJ, Murase N, Rao AS, Fung JJ, Starzl TE. Murine liver allograft transplantation: tolerance and donor cell chimerism. Hepatology. 1994;19(4):916-924.

5. Kamada N, Brons G, Davies HS. Fully allogeneic liver grafting in rats induces a state of systemic nonreactivity to donor transplantation antigens. Transplantation. 1980;29(5):429-431.

6. Zimmermann FA, Davies HS, Knoll PP, Gokel JM, Schmidt T. Orthotopic liver allografts in the rat. The influence of strain combination on the fate of the graft. Transplantation. 1984;37(4):406-410.

7. Kamada N, Wight DG. Antigen-specific immunosuppression induced by liver transplantation in the rat. Transplantation. 1984;38(3):217221.

8. Wang C, Sun J, Li L, Wang L, Dolan P, Sheil AG. Conversion of pancreas allograft rejection to acceptance by liver transplantation. Transplantation. 1998;65(2):188-192.

9. Kamada N, Davies HS, Roser B. Reversal of transplantation immunity by liver grafting. Nature. 1981;292(5826):840-842.

10. Lerut J, Sanchez-Fueyo A. An appraisal of tolerance in liver transplantation. American journal of transplantation. 2006;6(8):17741780. doi: 10.1111/j.1600-6143.2006.01396.x.

11. Alex Bishop G, Bertolino PD, Bowen DG, McCaughan GW. Tolerance in liver transplantation. Best Pract Res Clin Gastroenterol 2012;26(1):73-84. doi: 10.1016/j.bpg.2012.01.003.

12. Rasmussen A, Davies HF, Jamieson NV, Evans DB, Calne RY. Combined transplantation of liver and kidney from the same donor protects the kidney from rejection and improves kidney graft survival Transplantation. 1995;59(6):919-921.

13. Opelz G, Margreiter R, Dohler B. Prolongation of long-term kidney graft survival by a simultaneous liver transplant: the liver does it, and the heart does it too. Transplantation. 2002;74(10):1390-1394. doi: 10.1097/01.TP.0000034923.37376.9F.

14. Creput C, Durrbach A, Samuel D, Eschwege P, Amor M, Kriaa F, et al. Incidence of renal and liver rejection and patient survival rate following combined liver and kidney transplantation. Am J Transplant. 2003;3(3):348-356.

15. Morrissey PE, Gordon F, Shaffer D, Madras PN, Silva P, Sahyoun AI, et al. Combined liver-kidney transplantation in patients with cirrhosis and renal failure: effect of a positive cross-match and benefits of combined transplantation. Liver Transpl Surg: 1998;4(5):363-369

16. Olausson M, Mjornstedt L, Norden G, Rydberg L, Molne J, Backman
L, et al. Successful combined partial auxiliary liver and kidney transplantation in highly sensitized cross-match positive recipients. Am J Transplant. 2007;7(1):130-136. doi: 10.1111/j.16006143.2006.01592.x

17. Abu-Elmagd KM, Costa G, Bond GJ, Soltys K, Sindhi R, Wu T, et al. Five hundred intestinal and multivisceral transplantations at a single center: major advances with new challenges. Ann Surg. 2009;250(4):567-581. doi: 10.1097/SLA.0b013e3181b67725.

18. Schlitt HJ, Kanehiro H, Raddatz G, Steinhoff G, Richter N, Nashan B, et al. Persistence of donor lymphocytes in liver allograft recipients. Transplantation. 1993;56(4):1001-1007.

19.Verdonk RC, Haagsma EB, Jongsma T, Porte RJ, Roozendaal C, van den Berg AP, et al. A prospective analysis of the natural course of donor chimerism including the natural killer cell fraction after liver transplantation. Transplantation. 2011;92(4):e22-4. doi: 10.1097/ TP.0b013e318225283e.

20. Starzl TE, Demetris AJ, Trucco M, Ramos H, Zeevi A, Rudert WA, et al. Systemic chimerism in human female recipients of male livers. Lancet. 1992;340(8824):876-877.

21. Starzl TE, Zinkernagel RM. Transplantation tolerance from a historical perspective. Nat Rev Immunol. 2001;1(3):233-239. doi: 10.1038/35105088.

22. Shirwan H, Wang HK, Barwari L, Makowka L, Cramer DV. Pretransplant injection of allograft recipients with donor blood or lymphocytes permits allograft tolerance without the presence of persistent donor microchimerism. Transplantation. 1996;61(9):1382-1386.

23. Wood KJ, Evins J, Morris PJ. Suppression of renal allograft rejection in the rat by class I antigens on purified erythrocytes. Transplantation. 1985;39(1):56-62.

24. Josien R, Heslan M, Brouard S, Soulillou JP, Cuturi MC. Critical requirement for graft passenger leukocytes in allograft tolerance induced by donor blood transfusion. Blood. 1998;92(12):4539-4544.

25. Tsui TY, Deiwick A, Ko S, Schlitt HJ. Specific immunosuppression by postoperative infusion of allogeneic spleen cells: requirement of donor major histocompatibility complex expression and graft-versushost reactivity. Transplantation. 2000;69(1):25-30.

26. Yan Y, Shastry S, Richards C, Wang C, Bowen DG, Sharland AF, et al. Posttransplant administration of donor leukocytes induces long-term acceptance of kidney or liver transplants by an activation-associated immune mechanism. J Immunol. 2001;166(8):5258-5264.

27. Sun J, McCaughan GW, Gallagher ND, Sheil AG, Bishop GA. Deletion of spontaneous rat liver allograft acceptance by donor irradiation. Transplantation. 1995;60(3):233-236

28. Chiba S, Goto S, Shimizu Y, Vari F, Lord R, Edwards-Smith C, et al. The characterization of reconstituted passenger leukocytes on the induction of tolerance in rat liver transplantation. Transplant international : official journal of the European Society for Organ Transplantation. 1997;10(5):350-356.

29. Sriwatanawongsa V, Davies HS, Calne RY. The essential roles of parenchymal tissues and passenger leukocytes in the tolerance induced by liver grafting in rats. Nat Med. 1995;1(5):428-432.

30. Dresske B, Lin X, Huang DS, Zhou X, Fandrich F. Spontaneous tolerance: experience with the rat liver transplant model. Hum Immunol. 2002;63(10):853-861.

31. Salgar SK, Shapiro R, Dodson F, Corry R, McCurry K, Zeevi A, et al. Infusion of donor leukocytes to induce tolerance in organ allograft 
recipients. J Leukoc Biol. 1999;66(2):310-314.

32. Ciancio G, Miller J, Garcia-Morales RO, Carreno M, Burke GW, 3rd, Roth D, et al. Six-year clinical effect of donor bone marrow infusions in renal transplant patients. Transplantation. 2001;71(7):827-835.

33. Solgi G, Gadi V, Paul B, Mytilineos J, Pourmand G, Mehrsai A, et al. Fiveyear clinical effects of donor bone marrow cells infusions in kidney allograft recipients: improved graft function and higher graft survival. Chimerism. 2013;4(3):87-94. doi: 10.4161/chim.24719.

34. Monaco AP. Reflections on the unique tolerogenicity of bone marrow, the enigma of chimerism and clinical tolerance. Clin Transpl. 2013:157-66.

35. Bishop GA, Sun J, DeCruz DJ, Rokahr KL, Sedgwick JD, Sheil AG, et al. Tolerance to rat liver allografts. III. Donor cell migration and tolerance-associated cytokine production in peripheral lymphoid tissues. J Immunol. 1996;156(12):4925-4931.

36. Jones ND, Van Maurik A, Hara M, Gilot BJ, Morris PJ, Wood KJ. T-cell activation, proliferation, and memory after cardiac transplantation in vivo. Ann Surg. 1999;229(4):570-578.

37. Gilot BJ, Hara M, Jones ND, van Maurik A, Niimi M, Hadjianastassiou $\mathrm{V}$, et al. Visualization of the in vivo generation of donor antigenspecific effector CD8+ T cells during mouse cardiac allograft rejection: in vivo effector CD8+ $\mathrm{T}$ cell generation during allograft rejection. Transplantation. 2000;69(4):639-648.

38. Rokahr KL, Sharland AF, Sun J, Wang C, Sheil AG, Yan Y, et al Paradoxical early immune activation during acceptance of liver allografts compared with rejection of skin grafts in a rat model of transplantation. Immunology. 1998;95(2):257-263.

39. Sharland A, Yan Y, Wang C, Bowen DG, Sun J, Sheil AG, et al. Evidence that apoptosis of activated $\mathrm{T}$ cells occurs in spontaneous tolerance of liver allografts and is blocked by manipulations which break tolerance. Transplantation. 1999;68(11):1736-1745

40. Bishop GA, Wang C, Sharland AF, McCaughan G. Spontaneous acceptance of liver transplants in rodents: evidence that liver leucocytes induce recipient T-cell death by neglect. Immunol Cell Biol. 2002;80(1):93-100. doi: 10.1046/j.1440-1711.2002.01049. $\mathrm{x} 41$.

41. Lenardo MJ. Interleukin-2 programs mouse alpha beta $\mathrm{T}$ lymphocytes for apoptosis. Nature. 1991;353(6347):858-861. doi: 10.1038/353858a0.

42. Kneitz B, Herrmann T, Yonehara S, Schimpl A. Normal clonal expansion but impaired Fas-mediated cell death and anergy induction in interleukin-2-deficient mice. Eur J Immunol. 1995;25(9):25722577. doi: 10.1002/eji.1830250925.

43. Tu Y, Arima T, Flye MW. Rejection of spontaneously accepted rat liver allografts with recipientinterleukin-2 treatment or donor irradiation. Transplantation. 1997;63(2):177-181.

44. Qian S, Lu L, Fu F, Li Y, Li W, Starzl TE, et al. Apoptosis within spontaneously accepted mouse liver allografts: evidence for deletion of cytotoxic T cells and implications for tolerance induction. J Immunol. 1997;158(10):4654-4561.

45. Li W, Carper K, Liang Y, Zheng XX, Kuhr CS, Reyes JD, et al. AntiCD25 mAb administration prevents spontaneous liver transplant tolerance. Transplant Proc. 2006;38(10):3207-3208. doi: 10.1016/j. transproceed.2006.10.094

46. Schlitt HJ, Raddatz G, Steinhoff G, Wonigeit K, Pichlmayr R. Passenger lymphocytes in human liver allografts and their potential role after transplantation. Transplantation. 1993;56(4):951-955.

47. Sun J, Sheil AG, Wang C, Wang L, Rokahr K, Sharland A, et al. Tolerance to rat liver allografts: IV. Acceptance depends on the quantity of donor tissue and on donor leukocytes. Transplantation. 1996;62(12):17251730.

48. Thomson AW, Lu L. Are dendritic cells the key to liver transplant tolerance? Immunol Today. 1999;20(1):27-32.

49. Moroso V, Metselaar HJ, Mancham S, Tilanus HW, Eissens D, van der Meer A, et al. Liver grafts contain a unique subset of natural killer cells that are transferred into the recipient after liver transplantation. Liver Transpl. 2010;16(7):895-908. doi: 10.1002/lt.22080.

50.van Leest Y, Moroso V, Wang C, Tay SS, Cunningham E, Ilie V, et al. No evidence for involvement of donor NK cells in liver transplant tolerance. Transpl Immunol. 2011;24(2):138-9. doi: 10.1016/j. trim.2010.11.001.

51. Hisanaga M, Hundrieser J, Boker $\mathrm{K}$, Uthoff $\mathrm{K}$, Raddatz G, Wahlers T, et al. Development, stability, and clinical correlations of allogeneic microchimerism after solid organ transplantation. Transplantation. 1996;61(1):40-45.

52. Schlitt HJ, Hundrieser J, Hisanaga M, Uthoff K, Karck M, Wahlers T, et al. Patterns of donor-type microchimerism after heart transplantation. Lancet. 1994;343(8911):1469-1471.

53. Elwood ET, Larsen CP, Maurer DH, Routenberg KL, Neylan JF, Whelchel JD, et al. Microchimerism and rejection in clinical transplantation. Lancet. 1997;349(9062):1358-1360.

54. Schlitt HJ, Hundrieser J, Ringe B, Pichlmayr R. Donor-type microchimerism associated with graft rejection eight years after liver transplantation. N Engl J Med 1994;330(9):646-647. doi: 10.1056/ NEJM199403033300919.

55. Sivasai KS, Alevy YG, Duffy BF, Brennan DC, Singer GG, Shenoy S, et al. Peripheral blood microchimerism in human liver and renal transplant recipients: rejection despite donor-specific chimerism. Transplantation. 1997;64(3):427-432.

56. Ko S, Deiwick A, Jager MD, Dinkel A, Rohde F, Fischer R, et al. The functional relevance of passenger leukocytes and microchimerism for heart allograft acceptance in the rat. Nat Med. 1999;5(11):1292-1297. doi: $10.1038 / 15248$.

57. Bushell A, Pearson TC, Morris PJ, Wood KJ. Donor-recipient microchimerism is not required for tolerance induction following recipient pretreatment with donor-specific transfusion and anti-CD4 antibody. Evidence of a clear role for short-term antigen persistence. Transplantation. 1995;59(10):1367-1371.

58. Scully R, Qin S, Cobbold S, Waldmann H. Mechanisms in CD4 antibody-mediated transplantation tolerance: kinetics of induction, antigen dependency and role of regulatory T cells. Eur J Immunol. 1994;24(10):2383-2392. doi: 10.1002/eji.1830241019.

59. Chen ZK, Cobbold SP, Waldmann H, Metcalfe S. Amplification of natural regulatory immune mechanisms for transplantation tolerance. Transplantation. 1996;62(9):1200-1206.

60. Hamano K, Rawsthorne MA, Bushell AR, Morris PJ, Wood KJ. Evidence that the continued presence of the organ graft and not peripheral donor microchimerism is essential for maintenance of tolerance to alloantigen in vivo in anti-CD4 treated recipients. Transplantation. 1996;62(6):856-860.

61. Okumi M, Fishbein JM, Griesemer AD, Gianello PR, Hirakata A, Nobori $S$, et al. Role of persistence of antigen and indirect recognition in 
the maintenance of tolerance to renal allografts. Transplantation. 2008;85(2):270-280. doi: 10.1097/TP.0b013e31815e8eed.

62. Martinez-Llordella M, Puig-Pey I, Orlando G, Ramoni M, Tisone G, Rimola A, et al. Multiparameter immune profiling of operational tolerance in liver transplantation. Am J Transplant : 2007;7(2):309319.

63. Martinez-Llordella M, Lozano JJ, Puig-Pey I, Orlando G, Tisone G, Lerut $J$, et al. Using transcriptional profiling to develop a diagnostic test of operational tolerance in liver transplant recipients. J Clin Invest. 2008;118(8):2845-2857. doi: 10.1172/JCI35342.

64. Li L, Wozniak LJ, Rodder S, Heish S, Talisetti A, Wang Q, et al. A common peripheral blood gene set for diagnosis of operational tolerance in pediatric and adult liver transplantation. Am J Transplant. 2012;12(5):1218-1228. doi: 10.1111/j.1600-6143.2011.03928.x.

65. Bohne F, Martinez-Llordella M, Lozano JJ, Miquel R, Benitez C, Londono MC, et al. Intra-graft expression of genes involved in iron homeostasis predicts the development of operational tolerance in human liver transplantation. Journal Clin Invest. 2012;122(1):368382. doi: $10.1172 / J C I 59411$.

66. Puig-Pey I, Bohne F, Benitez C, Lopez M, Martinez-Llordella M, Oppenheimer F, et al. Characterization of gammadelta T cell subsets in organ transplantation. Transplant international. 2010;23(10):10451055. doi: 10.1111/j.1432-2277.2010.01095.x.

67. Li Y, Koshiba T, Yoshizawa A, Yonekawa Y, Masuda K, Ito A, et al Analyses of peripheral blood mononuclear cells in operational tolerance after pediatric living donor liver transplantation. Am J Transplant. 2004;4(12):2118-2125. doi: 10.1111/j.16006143.2004.00611.x.

68. Pons JA, Revilla-Nuin B, Baroja-Mazo A, Ramirez P, MartinezAlarcon L, Sanchez-Bueno F, et al. FoxP3 in peripheral blood is associated with operational tolerance in liver transplant patients during immunosuppression withdrawal. Transplantation. 2008;86(10):1370-8. doi: 10.1097/TP.0b013e318188d3e6.

69. Tokita D, Mazariegos GV, Zahorchak AF, Chien N, Abe M, Raimondi G, et al. High PD-L1/CD86 ratio on plasmacytoid dendritic cells correlates with elevated T-regulatory cells in liver transplant tolerance. Transplantation. 2008;85(3):369-377. doi: 10.1097/ TP.0b013e3181612ded.

70. Li Y, Zhao X, Cheng D, Haga H, Tsuruyama T, Wood K, et al. The presence of Foxp3 expressing $\mathrm{T}$ cells within grafts of tolerant human liver transplant recipients. Transplantation. 2008;86(12):1837-1843. doi: 10.1097/TP.0b013e31818febc4.

71. Thai NL, Qian S, Fu F, Li Y, Sun H, Demetris AJ, et al. Mouse liver transplantation tolerance: the role of hepatocytes and nonparenchymal cells. Transplantation proceedings. 1995;27(1):509-510.

72. Bertolino P, McCaughan GW, Bowen DG. Role of primary intrahepatic T-cell activation in the 'liver tolerance effect'. Immunology and cell biology. 2002;80(1):84-92. doi: 10.1046/j.08189641.2001.01048.x.11869365.

73. Warren A, Le Couteur DG, Fraser R, Bowen DG, McCaughan GW Bertolino P. T lymphocytes interact with hepatocytes through fenestrations in murine liver sinusoidal endothelial cells. Hepatology. 2006;44(5):1182-1190.

74. Bertolino P, Trescol-Biemont MC, Rabourdin-Combe C. Hepatocytes induce functional activation of naive CD8+ T lymphocytes but fail to promote survival. European journal of immunology. 1998;28(1):221236.
75. Bertolino P, Bowen DG, McCaughan GW, Fazekas de St Groth B. Antigen-specific primary activation of CD8+ T cells within the liver. J Immunol. 2001;166(9):5430-5438.

76. Herkel J, Jagemann B, Wiegard C, Lazaro JF, Lueth S, Kanzler S, et al. MHC class II-expressing hepatocytes function as antigen-presenting cells and activate specific CD4 T lymphocyutes. Hepatology. 2003;37(5):1079-1085. doi: 10.1053/jhep.2003.50191.

77. Lohse AW, Knolle PA, Bilo K, Uhrig A, Waldmann C, Ibe M, et al. Antigen-presenting function and B7 expression of murine sinusoidal endothelial cells and Kupffer cells. Gastroenterology. 1996;110(4):1175-1181.

78. Knolle P, Schlaak J, Uhrig A, Kempf P, Meyer zum Buschenfelde KH, Gerken G. Human Kupffer cells secrete IL-10 in response to lipopolysaccharide (LPS) challenge. J Hepatol. 1995;22(2):226-229.

79. Le Moine O, Marchant A, Durand F, Ickx B, Pradier O, Belghiti J, et al. Systemic release of interleukin-10 during orthotopic liver transplantation. Hepatology. 1994;20(4 Pt 1):889-892.

80. Ingelsten M, Gustafsson K, Olausson M, Haraldsson B, Karlsson-Parra A, Nystrom J. Rapid increase of interleukin-10 plasma levels after combined auxiliary liver-kidney transplantation in presensitized patients. Transplantation. 2014;98(2):208-15. doi: 10.1097/ TP.0000000000000038.

81. Groux H, Bigler M, de Vries JE, Roncarolo MG. Interleukin-10 induces a long-term antigen-specific anergic state in human CD4+ T cells. J Exp Med. 1996;184(1):19-29.

82. Knolle PA, Gerken G. Local control of the immune response in the liver. Immunol Rev. 2000;174:21-34.

83. Roland CR, Walp L, Stack RM, Flye MW. Outcome of Kupffer cell antigen presentation to a cloned murine Th1 lymphocyte depends on the inducibility of nitric oxide synthase by IFN-gamma. J Immunol. 1994;153(12):5453-5464.

84. You Q, Cheng L, Kedl RM, Ju C. Mechanism of T cell tolerance induction by murine hepatic Kupffer cells. Hepatology. 2008;48(3):978-990. doi: 10.1002/hep.22395.

85. Chen Y, Liu Z, Liang S, Luan X, Long F, Chen J, et al. Role of Kupffer cells in the induction of tolerance of orthotopic liver transplantation in rats. Liver transplantation 2008;14(6):823-836. doi: 10.1002/lt.21450.

86. Rubinstein D, Roska AK, Lipsky PE. Liver sinusoidal lining cells express class II major histocompatibility antigens but are poor stimulators of fresh allogeneic T lymphocytes. J Immunol. 1986;137(6):1803-1810.

87. Knolle PA, Schmitt E, Jin S, Germann T, Duchmann R, Hegenbarth $\mathrm{S}$, et al. Induction of cytokine production in naive CD4(+) T cells by antigen-presenting murine liver sinusoidal endothelial cells but failure to induce differentiation toward Th1 cells. Gastroenterology. 1999;116(6):1428-1440.

88. Klugewitz K, Blumenthal-Barby F, Schrage A, Knolle PA, Hamann A, Crispe IN. Immunomodulatory effects of the liver: deletion of activated CD4+ effector cells and suppression of IFN-gammaproducing cells after intravenous protein immunization. J Immunol. 2002;169(5):2407-2413.

89. Limmer A, Ohl J, Kurts C, Ljunggren HG, Reiss Y, Groettrup M, et al. Efficient presentation of exogenous antigen by liver endothelial cells to CD8+ T cells results in antigen-specific T-cell tolerance. Nat Med. 2000;6(12):1348-1354. doi: 10.1038/82161.

90. Bertolino P, Trescol-Biemont MC, Thomas J, Fazekas de St Groth B, Pihlgren M, Marvel J, et al. Death by neglect as a deletional mechanism 
of peripheral tolerance. Int Immunol. 1999;11(8):1225-1238.

91. Diehl L, Schurich A, Grochtmann R, Hegenbarth S, Chen L, Knolle PA. Tolerogenic maturation of liver sinusoidal endothelial cells promotes B7-homolog 1-dependent CD8+ $\mathrm{T}$ cell tolerance. Hepatology. 2008;47(1):296-305. doi: 10.1002/hep.21965.

92. Steinman RM, Hawiger D, Nussenzweig MC. Tolerogenic dendritic cells. Annu Rev Immunol. 2003;21:685-711. doi: 10.1146/annurev. immunol.21.120601.141040.

93. Buelens C, Verhasselt V, De Groote D, Thielemans K, Goldman M, Willems F. Human dendritic cell responses to lipopolysaccharide and CD40 ligation are differentially regulated by interleukin-10. Eur J Immunol. 1997;27(8):1848-1852. doi: 10.1002/eji.1830270805.

94. Khanna A, Morelli AE, Zhong C, Takayama T, Lu L, Thomson AW. Effects of liver-derived dendritic cell progenitors on Th1- and Th2-like cytokine responses in vitro and in vivo. J Immunol. 2000;164(3):13461354.

95. Woo J, Lu L, Rao AS, Li Y, Subbotin V, Starzl TE, et al. Isolation, phenotype, and allostimulatory activity of mouse liver dendritic cells. Transplantation. 1994;58(4):484-491.

96. Pillarisetty VG, Shah AB, Miller G, Bleier JI, DeMatteo RP. Liver dendritic cells are less immunogenic than spleen dendritic cells because of differences in subtype composition. J Immunol. 2004;172(2):10091017.

97. Lu L, McCaslin D, Starzl TE, Thomson AW. Bone marrow-derived dendritic cell progenitors (NLDC 145+, MHC class II+, B7-1dim, B72-) induce alloantigen-specific hyporesponsiveness in murine $\mathrm{T}$ lymphocytes. Transplantation. 1995;60(12):1539-1545.

98. Lutz MB, Suri RM, Niimi M, Ogilvie AL, Kukutsch NA, Rossner S, et al. Immature dendritic cells generated with low doses of GM-CSF in the absence of IL-4 are maturation resistant and prolong allograft survival in vivo. Euro J Immunol. 2000;30(7):1813-22. doi: 10.1002/15214141.

99. Lian ZX, Okada T, He XS, Kita H, Liu YJ, Ansari AA, et al. Heterogeneity of dendritic cells in the mouse liver: identification and characterization of four distinct populations. J Immunol. 2003;170(5):2323-2330.

100. Bamboat ZM, Stableford JA, Plitas G, Burt BM, Nguyen HM, Welles AP, et al. Human liver dendritic cells promote $\mathrm{T}$ cell hyporesponsiveness. J Immunol. 2009;182(4):1901-11. doi: 10.4049/jimmunol.0803404.

101. Dhodapkar MV, Steinman RM, Krasovsky J, Munz C, Bhardwaj N. Antigen-specific inhibition of effector T cell function in humans after injection of immature dendritic cells. J Exp Med. 2001;193(2):233238.

102. Dhodapkar MV, Steinman RM. Antigen-bearing immature dendritic cells induce peptide-specific CD8(+) regulatory $\mathrm{T}$ cells in vivo in humans. Blood. 2002;100(1):174-177.

103. Cabillic F, Rougier N, Basset C, Lecouillard I, Quelvennec E, Toujas $\mathrm{L}$, et al. Hepatic environment elicits monocyte differentiation into a dendritic cell subset directing Th2 response. J Hepatol. 2006;44(3):552-559. doi: 10.1016/j.jhep.2005.08.010.

104. Moseman EA, Liang X, Dawson AJ, Panoskaltsis-Mortari A, Krieg AM, Liu YJ, et al. Human plasmacytoid dendritic cells activated by CpG oligodeoxynucleotides induce the generation of CD4+CD25+ regulatory T cells. J Immunol. 2004;173(7):4433-4442.

105. Ito T, Yang M, Wang YH, Lande R, Gregorio J, Perng OA, et al Plasmacytoid dendritic cells prime IL-10-producing $\mathrm{T}$ regulatory cells by inducible costimulator ligand. J Exp Med. 2007;204(1):105-

\section{5. doi: $10.1084 /$ jem.20061660}

106. Probst HC, McCoy K, Okazaki T, Honjo T, van den Broek M. Resting dendritic cells induce peripheral CD8+ T cell tolerance through PD-1 and CTLA-4. Nat Immunol. 2005;6(3):280-286. doi: 10.1038/ ni1165.

107. Fu F, Li Y, Qian S, Lu L, Chambers F, Starzl TE, et al. Costimulatory molecule-deficientdendritic cell progenitors (MHCclass II+,CD80dim, CD86-) prolong cardiac allograft survival in nonimmunosuppressed recipients. Transplantation. 1996;62(5):659-665.

108. Lu L, Li W, Fu F, Chambers FG, Qian S, Fung JJ, et al. Blockade of the CD40-CD40 ligand pathway potentiates the capacity of donorderived dendritic cell progenitors to induce long-term cardiac allograft survival. Transplantation. 1997;64(12):1808-1815.

109. Steptoe RJ, Li W, Fu F, O’Connell PJ, Thomson AW. Trafficking of APC from liver allografts of Flt3L-treated donors: augmentation of potent allostimulatory cells in recipient lymphoid tissue is associated with a switch from tolerance to rejection. Transplant Immunol. 1999;7(1):51-57.

110. Winau F, Hegasy G, Weiskirchen R, Weber S, Cassan C, Sieling PA, et al. Ito cells are liver-resident antigen-presenting cells for activating $\mathrm{T}$ cell responses. Immunity. 2007;26(1):117-29. doi: 10.1016/j. immuni.2006.11.011

111. Gressner AM, Weiskirchen R, Breitkopf K, Dooley S. Roles of TGFbeta in hepatic fibrosis. Front Biosci. 2002;7:d793-807.

112. Yu MC, Chen CH, Liang X, Wang L, Gandhi CR, Fung JJ, et al. Inhibition of T-cell responses by hepatic stellate cells via B7-H1-mediated T-cell apoptosis in mice. Hepatology. 2004;40(6):1312-1321. doi: 10.1002/hep.20488.

113. Weiskirchen R, Tacke F. Cellular and molecular functions of hepatic stellate cells in inflammatory responses and liver immunology. Hepatobiliary Surg and Nutr. 2014;3(6):344-363. doi: 10.3978/j. issn.2304-3881.2014.11.03.

114. Benten D, Kumaran V, Joseph B, Schattenberg J, Popov Y, Schuppan D, et al. Hepatocyte transplantation activates hepatic stellate cells with beneficial modulation of cell engraftment in the rat. Hepatology. 2005;42(5):1072-1081. doi: 10.1002/hep.20889.

115. Chen CH, Kuo LM, Chang Y, Wu W, Goldbach C, Ross MA, et al. In vivo immune modulatory activity of hepatic stellate cells in mice. Hepatology. 2006;44(5):1171-1181. doi: 10.1002/hep.21379.

116. Ganbold A, Andersen S, Tay SS, Cunningham E, Ilie V, Krishnan S, et al. Expression of common gamma chain signalling cytokines and their receptors distinguishes rejection from tolerance in a rat organ transplant model. Transpl Immunol. 2012;27(2-3):89-94. doi: 10.1016/j.trim.2012.08.001.

117. He C, Schenk S, Zhang Q, Valujskikh A, Bayer J, Fairchild RL, et al. Effects of T cell frequency and graft size on transplant outcome in mice. J Immunol. 2004;172(1):240-247.

118. Cunningham EC, Sharland AF, Bishop GA. Liver transplant tolerance and its application to the clinic: can we exploit the high dose effect? Clin Dev Immunol. 2013;2013:419692. doi: 10.1155/2013/419692.

119. Medawar PB. The behaviour and fate of skin autografts and skin homografts in rabbits: A report to the War Wounds Committee of the Medical Research Council. Journal of anatomy. 1944;78(Pt 5):176199.

120. Zanella G, Reif AE, Buenviaje OL, Asakuma R, Deterlig RA, Jr. On prolonged survival of massive skin allografts in mice. 
Transplantation. 1968;6(8):885-894.

121. Lappe MA, Graff RG, Snell GD. The importance of target size in the destruction of skin grafts with non-H-2 incompatibility. Transplantation. 1969;7(5):372-377.

122. Wang C, Sheil AG, Sun J. Outcome of different models of multiorgan transplantation in rats. Microsurgery. 1999;19(7):318-323.

123. Madsen JC, Yamada K, Allan JS, Choo JK, Erhorn AE, Pins MR, et al Transplantation tolerance prevents cardiac allograft vasculopathy in major histocompatibility complex class I-disparate miniature swine. Transplantation. 1998;65(3):304-313.

124. Fong TL, Bunnapradist S, Jordan SC, Selby RR, Cho YW. Analysis of the United Network for Organ Sharing database comparing renal allografts and patient survival in combined liver-kidney transplantation with the contralateral allografts in kidney alone or kidney-pancreas transplantation. Transplantation. 2003;76(2):348353.

125. Simpson N, Cho YW, Cicciarelli JC, Selby RR, Fong TL. Comparison of renal allograft outcomes in combined liver-kidney transplantation versus subsequent kidney transplantation in liver transplant recipients: Analysis of UNOS Database. Transplantation. 2006;82(10):1298-1303. doi: 10.1097/01.tp.0000241104.58576. e6.

126. Sarwal MM, Cecka JM, Millan MT, Salvatierra O, Jr. Adult-size kidneys without acute tubular necrosis provide exceedingly superior long-term graft outcomes for infants and small children: a single center and UNOS analysis. United Network for Organ Sharing. Transplantation. 2000;70(12):1728-1736.

127. Dirsch O, Li J, He Q, Ji Y, Gu YL, Dahmen U. Induction of rejection after small-for-size liver transplantation: size matters. Journal of investigative surgery . 2008;21(5):288-298. doi: 10.1080/08941930802216823.

128. Shiraishi M, Csete ME, Yasunaga C, Drazan KE, Jurim O, Cramer DV, et al. Regeneration-induced accelerated rejection in reduced-size liver grafts. Transplantation. 1994;57(3):336-340.

129. Yang ZF, Ho DW, Chu AC, Wang YQ, Fan ST. Linking inflammation to acute rejection in small-for-size liver allografts: the potential role of early macrophage activation. Am J Transplant. 2004;4(2):196-209.

130. Suh KS, Kim SB, Chang SH, Kim SH, Minn KW, Park MH, et al. Significance of positive cytotoxic cross-match in adult-to-adult living donor liver transplantation using small graft volume. Liver Transpl. 2002;8(12):1109-1113. doi: 10.1053/jlts.2002.37001.

131. Rana A, Robles S, Russo MJ, Halazun KJ, Woodland DC, Witkowski P, et al. The combined organ effect: protection against rejection? Ann Sur. 2008;248(5):871-879. doi: 10.1097/SLA.0b013e31817fc2b8.

132. Narula J, Bennett LE, DiSalvo T, Hosenpud JD, Semigran MJ, Dec GW. Outcomes in recipients of combined heart-kidney transplantation: multiorgan, same-donor transplant study of the International Society of Heart and Lung Transplantation/United Network for Organ Sharing Scientific Registry. Transplantation. 1997;63(6):861867.

133. Pinderski LJ, Kirklin JK, McGiffin D, Brown R, Naftel DC, Young KR, Jr., et al. Multi-organ transplantation: is there a protective effect against acute and chronic rejection? J Heart Lung Transplant. 2005;24(11):1828-1833. doi: 10.1016/j.healun.2005.03.015.

134. Lee WP, Yaremchuk MJ, Pan YC, Randolph MA, Tan CM, Weiland AJ. Relative antigenicity of components of a vascularized limb allograft. Plastic Reconstr Sur. 1991;87(3):401-411.
135. Astarcioglu I, Cursio R, Reynes M, Gugenheim J. Increased risk of antibody-mediated rejection of reduced-size liver allografts. The Journal of surgical research. 1999;87(2):258-262. doi: 10.1006/ jsre.1999.5734

136. Davies HS, Pollard SG, Calne RY. Soluble HLA antigens in the circulation of liver graft recipients. Transplantation. 1989;47(3):524527.

137. Sumimoto R, Kamada N. Specific suppression of allograft rejection by soluble class I antigen and complexes with monoclonal antibody. Transplantation. 1990;50(4):678-682.

138. Geissler EK, Korzun WJ, Graeb C. Secreted donor-MHC class I antigen prolongs liver allograft survival and inhibits recipient anti-donor cytotoxic $\mathrm{T}$ lymphocyte responses. Transplantation. 1997;64(5):782-786

139. Geissler EK, Graeb C, Tange S, Guba M, Jauch KW, Scherer MN. Effective use of donor MHC class I gene therapy in organ transplantation: prevention of antibody-mediated hyperacute heart allograft rejection in highly sensitized rat recipients. Hum Gene Ther . 2000;11(3):459-469. doi: 10.1089/10430340050015923.

140. Graeb C, Justl M, Scherer MN, Andrassy J, Frank E, Zuelke C, et al. Use of an adenoviral vector to express soluble donor-major histocompatibility complex molecules capable of suppressing the immune response in rat transplant recipients. Human immunology. 2002;63(10):844-852.

141. Zavazava N, Kronke M. Soluble HLA class I molecules induce apoptosis in alloreactive cytotoxic T lymphocytes. Nature medicine. 1996;2(9):1005-1010.

142. Taner T, Gandhi MJ, Sanderson SO, Poterucha CR, De Goey SR, Stegall MD, et al. Prevalence, course and impact of HLA donor-specific antibodies in liver transplantation in the first year. American journal of transplantation. Transplant Surgeons. 2012;12(6):1504-1510. doi: 10.1111/j.1600-6143.2012.03995.x.

143. Dar W, Agarwal A, Watkins C, Gebel HM, Bray RA, Kokko KE, et al. Donor-directed MHC class I antibody is preferentially cleared from sensitized recipients of combined liver/kidney transplants. Am J Transplant 2011;11(4):841-847. doi: 10.1111/j.16006143.2011.03467.x.

144. O’Leary JG, Gebel HM, Ruiz R, Bray RA, Marr JD, Zhou XJ, et al. Class II alloantibody and mortality in simultaneous liver-kidney transplantation. Am J Transplant. 2013;13(4):954-60. doi: 10.1111/ ajt.12147.

145. Gugenheim J, Le Thai B, Rouger P, Gigou M, Gane P, Vial MC, et al. Relationship between the liver and lymphocytotoxic alloantibodies in inbred rats. Specific absorption by nonparenchymal liver cells. Transplantation. 1988;45(2):474-478.

146. Gugenheim J, Amorosa L, Gigou M, Fabiani B, Rouger P, Gane P, et al. Specific absorption of lymphocytotoxic alloantibodies by the liver in inbred rats. Transplantation. 1990;50(2):309-313.

147. Rouas-Freiss N, Marchal RE, Kirszenbaum M, Dausset J, Carosella ED. The alpha1 domain of HLA-G1 and HLA-G2 inhibits cytotoxicity induced by natural killer cells: is HLA-G the public ligand for natural killer cell inhibitory receptors? Proc Natl Acad Sci U S A. 1997;94(10):5249-5254.

148. Le Gal FA, Riteau B, Sedlik C, Khalil-Daher I, Menier C, Dausset J, et al. HLA-G-mediated inhibition of antigen-specific cytotoxic $\mathrm{T}$ lymphocytes. International immunology. 1999;11(8):1351-1356.

149. Bainbridge DR, Ellis SA, Sargent IL. HLA-G suppresses proliferation 
of CD4(+) T-lymphocytes. J Reprod Immunol. 2000;48(1):17-26.

150. Lila N, Rouas-Freiss N, Dausset J, Carpentier A, Carosella ED. Soluble HLA-G protein secreted by allo-specific CD4+ T cells suppresses the allo-proliferative response: a CD4+ $\mathrm{T}$ cell regulatory mechanism. Proc Natl Acad Sci U S A. 2001;98(21):12150-12155. doi: 10.1073/ pnas.201407398.

151. Kanai T, Fujii T, Kozuma S, Yamashita T, Miki A, Kikuchi A, et al. Soluble HLA-G influences the release of cytokines from allogeneic peripheral blood mononuclear cells in culture. Mol Hum Reprod. 2001;7(2):195-200

152. Bahri R, Hirsch F, Josse A, Rouas-Freiss N, Bidere N, Vasquez A, et al Soluble HLA-G inhibits cell cycle progression in human alloreactive T lymphocytes. J Immunol. 2006;176(3):1331-1339.

153. LeMaoult J, Caumartin J, Daouya M, Favier B, Le Rond S, Gonzalez $\mathrm{A}$, et al. Immune regulation by pretenders: cell-to-cell transfers of HLA-G make effector T cells act as regulatory cells. Blood. 2007;109(5):2040-2048. doi: 10.1182/blood-2006-05-024547.

154. Ristich V, Liang S, Zhang W, Wu J, Horuzsko A. Tolerization of dendritic cells by HLA-G. Eur J Immunol. 2005;35(4):1133-11`42. doi: 10.1002/eji.200425741.

155. Fainardi E, Rizzo R, Melchiorri L, Vaghi L, Castellazzi M, Marzola A, et al. Presence of detectable levels of soluble HLA-G molecules in CSF of relapsing-remitting multiple sclerosis: relationship with CSF soluble HLA-I and IL-10 concentrations and MRI findings. J Neuroimmunol. 2003;142(1-2):149-158.

156. Verbruggen LA, Rebmann V, Demanet C, De Cock S, GrosseWilde H. Soluble HLA-G in rheumatoid arthritis. Hum Immunol. 2006;67(8):561-567. doi: 10.1016/j.humimm.2006.03.023.

157. Pistoia V, Morandi F, Wang X, Ferrone S. Soluble HLA-G: Are they clinically relevant? Semin Cancer Biol. 2007;17(6):469-79. doi: 10.1016/j.semcancer.2007.07.004.

158. Qiu J, Terasaki PI, Miller J, Mizutani K, Cai J, Carosella ED. Soluble HLA-G expression and renal graft acceptance. Amer J Transplant. 2006;6(9):2152-2156. doi: 10.1111/j.1600-6143.2006.01417.x.

159. Crispim JC, Duarte RA, Soares CP, Costa R, Silva JS, MendesJunior CT, et al. Human leukocyte antigen-G expression after kidney transplantation is associated with a reduced incidence of rejection. Transplant Immunol. 2008;18(4):361-7. doi: 10.1016/j. trim.2007.10.010.

160. Lu N, Zhang Y, Zou X, Yang X, Tian J, Zhen J, et al. HLA-G on peripheral blood CD4(+) T lymphocytes: a potential predictor for acute renal rejection. Transpl Int. 2011;24(11):1103-11. doi: 10.1111/j.14322277.2011.01314.x.

161. Lila N, Amrein C, Guillemain R, Chevalier P, Latremouille C, Fabiani $\mathrm{JN}$, et al. Human leukocyte antigen-G expression after heart transplantation is associated with a reduced incidence of rejection. Circulation. 2002;105(16):1949-54.

162. Luque J, Torres MI, Aumente MD, Marin J, Garcia-Jurado G, Gonzalez R, et al. Soluble HLA-G in heart transplantation: their relationship to rejection episodes and immunosuppressive therapy. Human immunology. 2006;67(4-5):257-263. doi: 10.1016/j. humimm.2006.02.034.

163. Levitsky J, Miller J, Wang E, Rosen A, Flaa C, Abecassis M, et al. Immunoregulatory profiles in liver transplant recipients on different immunosuppressive agents. Hum Immunol. 2009;70(3):146-150. doi: 10.1016/j.humimm.2008.12.008.

164. Akhter A, Das V, Naik S, Faridi RM, Pandey A, Agrawal S. Upregulation of HLA-G in JEG-3 cells by dexamethasone and hydrocortisone. Archives of gynecology and obstetrics. 2012;285(1):7-14. doi: 10.1007/s00404-011-1880-3.

165. Hu WY, Wu LQ, Su Z, Pang XF, Zhang B. Expression of human leukocyte antigen- $G$ and acute rejection in patients following liver transplantation. Exp Ther Med. 2014;8(4):1291-1295. doi: 10.3892/ etm.2014.1917.

166. Castellaneta A, Mazariegos GV, Nayyar N, Zeevi A, Thomson AW. HLA-G level on monocytoid dendritic cells correlates with regulatory T-cell Foxp3 expression in liver transplant tolerance. Transplantation. 2011;91(10):1132-1140. doi: 10.1097/ TP.0b013e31821414c9.

167. Creput C, Durrbach A, Menier C, Guettier C, Samuel D, Dausset J, et al. Human leukocyte antigen-G (HLA-G) expression in biliary epithelial cells is associated with allograft acceptance in liver-kidney transplantation. J Hepatol. 2003;39(4):587-94.

168. Creput C, Le Friec G, Bahri R, Amiot L, Charpentier B, Carosella E, et al. Detection of HLA-G in serum and graft biopsy associated with fewer acute rejections following combined liver-kidney transplantation: possible implications for monitoring patients. Hum Immunol. 2003;64(11):1033-1038.

169. Zarkhin V, Talisetti A, Li L, Wozniak LJ, McDiarmid SV, Cox K, et al. Expression of soluble HLA-G identifies favorable outcomes in liver transplant recipients. Transplantation. 2010;90(9):1000-5. doi: 10.1097/TP.0b013e3181f546af. 